\title{
第10章 光放射の応用
}

\section{主査 河本 康太郎（社）日本電球工業会）}

1997年の総説でも述べたが，人間にとって光が重要であるのは，光が下記の 4 つ重要な機能を持っているからである.

(1)人間が生活していくうえでの重要感覚である視覚支援の媒体

(2)人間の生活の基礎となっているエネルギーの一様態

(3)人間生活に不可欠な情報処理のためのメディア

(4)人間生活を豊かかつ快適にする機能要素（光アートなど）

照明年報のなかで本章が扱う範囲は上の(2)と(3)とに関連が深い。したがって，たとえば取り扱う光源も，視覚支援を目的とす る一般照明用光源よりも種類もバリエーションも多く, レーザ, LED も含まれることになる.

これらの光源のなかで, 本年(1998年), LEDについて注目すべき動向が見られた. LEDはもともと上記の区分でいうと(3)に関 連が深く道路交通信号や交通情報システムやディスプレイ装置, 赤外リモコンなど情報システム用の光源として広く活用されて きているが, 荷電粒子の再結合による発光過程の電気一光エネルギー変換効率が, 将来さらに改良されていく可能性が大きいこ とが注目され，一般照明用光源としての将来性の総合的検討が開始された.

すなわち, 通産省の外郭団体である金属系材料研究開発センターが, 新研究開発プロジェクト「21世紀のあかり計画」を新エ ネルギー・産業技術総合開発機構からの委託を受けて, 本年（1998年）9月よクスタートさせている. 一般照明用白色 LED 実現 のための効率の向上目標值は, 蛍光ランプの 2 倍以上（点灯回路を含んだ総合効率が $180 \mathrm{Im} / \mathrm{W}$ 以上）である. 現在の情報シス テム用の LED の効率は, 赤一黄色 LED および緑色 LED の場合で $40 \mathrm{Im} / \mathrm{W}$, 白色 LED は, 青一黄色の組み合わせの場合で $10 \mathrm{Im} / \mathrm{W}$ UV-LED+蛍光体の場合で $40 \mathrm{~lm} / \mathrm{W}$ 程度であり,「21世紀のあかり計画」の目標は高く, 達成には幾多のブレークスルーが必要と 考えられるが, 本章の関連である情報システム関連の技術が一般照明の分野に展開していくのは誠に喜ばしいことであり, 技術 開発の成果を期待したい.

また LED は一般照明用ではないが, 現在すでに植物育成や医療など, 光エネルギーの利用分野 (上記の(2)の分野) への展開も 検討されており，21世紀の光源としての期待が大きくなってきている.

光環境 (lighted environment) における重要構成要素としての光放射の人間・生物に対する機能・作用についても種々の視点 から技術開発が進展したが, その成果の集大成の一環として, 本年（1998年）７月に成書「照明学会編：UVと生物産業」が侏養 賢堂より上梓された。この著書の背景技術のひとつとなっている光放射の環境関連問題一太陽紫外放射の作用や, 光害など人間 の生理・行動に対する光放射の作用の問題, また, 環境問題以外の医療や殺菌, 電熱などの光・放射エネルギ一利用技術の関連 問題, リモートセンシング, オプトエレクトロニクス, 情報システム関連問題など, 各論についてもそれぞれの技術的進展・展 開が見られた。詳細は以下の各節の記述をご参照いただきたい.

\section{1 紫外放射源と作用効果}

紫外域の分光計測に重要な重水素ランプの経時変化の50\%は空 材の劣化で, フッソドープ Si ガラスに変えると劣化が押さえられ るが, ノーズの長いランプでは改善されないと報告された ${ }^{1)}$ レー ザリソグラフィ一用の出力 $266 \mathrm{~nm}$ で数 $100 \mathrm{~mW}, 231 \mathrm{~nm}$ で $100 \mathrm{~mW}$ の小型固体 UVレーザ2)，Cu蒸気レーザの第 2 高調波 $255 \mathrm{~nm}$ で $4.7 \mathrm{~W}$ 光源 ${ }^{31}$, レーザダイオードの周波数変換による波長可変 UV $\left(W^{4)}\right.$ などが開発され, UVファイバレーザ5), 非線形光学結晶を用 いた第 5 高調波のDeep UVレーザ(やや長パルス紫外レーザ光 源7), 紫外吸収センサのためのシンチレー夕光源8などが紹介され た. 光計測の主センサ, シリコンフォトダイオードの $250 〜 850 \mathrm{~nm}$ 域の高精度な分光反射率が報告された ${ }^{91}$. 短波長劣化が避けられ ない Siフォトダーオードに変わる紫外放射検出器として, 250〜 $320 \mathrm{~nm}$ に感度を持つ $\mathrm{ZnS}$ 単結晶の太陽ブラインド型光セン サ10)，GaN pin センサ111が開発された。また，個人が被爆する紫 外放射量を計測するフォトクロミックセンサ ${ }^{12)}$ ，太陽 UV 用の酵

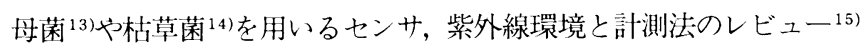
紅斑線量で重み付けされた 6 夕イプの带域分光型 UV 計を16力 国が参加して相互比較を行い, 太陽高度角35度以上の測定で感度

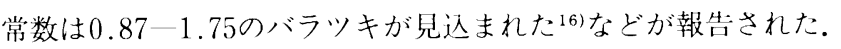
紫外放射源の産業利用は多彩で, YAGレーザ高調波の工業利 用の可能性 17), 真空紫外ラマンレーザと多重波長励起プロセッシ ングの理化学研究所の開発状況 ${ }^{18)}$, UV コーテイングにおける散 乱の課題 ${ }^{199}$, UV 硬化エポキシアクリレート防食塗装の接着に対 する高分子結合剂効果の比較 ${ }^{201}$, 高分子コレステリックネットワー ク構造と電気光学特性八の UV 硬化条件 ${ }^{21)}$, 環境問題とUV 硬化 塗料の改善点 ${ }^{22)}$, UV 書き込み平面導波路の屈折率変化のモデ ル $^{23)}$, 非線形光学導波路形成への UV ブリ-ーチング効果 ${ }^{24)}$, 酸化 チタン光触媒担持シートの開発25)などが報告された.

成層圈オゾンの減少は南極で過去最大を記録し ${ }^{26)}$, 太陽 UV-B の増加も明らかになりつつある ${ }^{27)}$. 太陽紫外放射の皮膚影響は, 皮

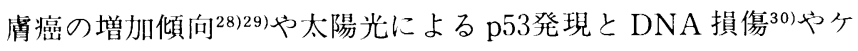
ラチン細胞内での JNK1の活性化 ${ }^{31}$ が報告された。また, UV-A

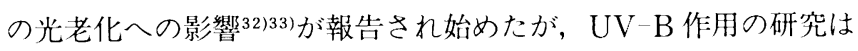
数多く, ケラチン細胞に扔けるビタミン D 受容体遺伝子発現の抑 制 ${ }^{34)}$, 長期暴露がしわやたるみをもたらす35)-37)こと, 個人被爆量 は高度, 気象条件, 上卜の行動に依存すること ${ }^{38)}$, 皮膚の紫外放射 
劣化の細胞レベルでの反応機構 ${ }^{39)}$, UV 化粧品の日焼け止め効果 テスト ${ }^{40)}$ ，サンスクリーン剂の現状と将来 ${ }^{41) な と ゙ か ゙ あ る 。 そ の ほ ~}$ か, UV-B が急性そう状苔せん状U糠疹の治療に有効 ${ }^{42)}$ との報告 や前立腺癌の内服薬フルタミドで $\mathrm{UV}-\mathrm{A}$ 光線過敏が発生した 例 ${ }^{43)}$, 光毒性の歴史的レビュ—44), 七卜毛髮の UV 損傷 ${ }^{45)}$, 皮膚に 分布寸るUV 防御物質吕カニン酸の異性体定量法 ${ }^{46)}$, 屋外の各 種環境での太陽紫外 UV-A と UV-B 放射量の計測と評価 ${ }^{47)}$, CIE の紅斑参照スペクトルと標準紅斑量が報告され ${ }^{48)}$ ，また太陽放射 より UV-Aも UV-Bも多く放射する市販の sunlampの皮膚へ の危険性 ${ }^{49)}$ も指摘された。

紫外放射が白内障誘発因子であること ${ }^{50)-52)}$, 加齢時の水唱体ク リスタリンの凝集が $\mathrm{UV}-\mathrm{A}$ によって発生する 1 重項酸素のアス コルビン酸やグルタチオンによる捕捉障壁となること ${ }^{53)}, \mathrm{UV}-\mathrm{A}$ 照射が高グルタチオン存在下でもアスコルビン酸の酸化を起こす こと54などが報告され，紫外放射からの目の保護の重要性がサン グラスの欧州規格 ${ }^{55)}$ ともに提示された。

な㧍，太陽紫外線の人体影響についての関心は本年も大きく， 日本香粧品科学会誌, 医用紫外線研究会誌, 太陽紫外線防御研究 委員会学術報告などに多数の研究報告が掲載され，単行本，太陽 紫外線と健康 ${ }^{56)}$, 皮膚の老化 ${ }^{57)}$ も出版された。

動植物への紫外放射の影響について研究成果が出はじめてき た. 動物関連では，各359，358，359，393nmに吸収極大をもつ囬 椎動物マウス, ラット, キンギョ, ハト類の紫外視覚の分子機構 ${ }^{58)}$, 両棲類の卵と幼生への UV-B 影響実験における問題点 ${ }^{59)}$, 昆虫病 原性線虫とその共生細菌への UV-B の殺作用 ${ }^{60}$ ) ほ乳類細胞に対 するUVの毒性ストレスの誘導 ${ }^{61)}$ ，水性生態系 ${ }^{62)}$ や水性無脊椎動 物への UV-B 影響の評価法 ${ }^{63)}$, 藍藻類の肝臓毒素ミクロシスチン$\mathrm{LR} の \mathrm{UV}$ 解毒作用 ${ }^{64)}$, 赤潮発生を妨害する $\mathrm{UV}-\mathrm{A}$ 吸収藻類の存 在と役割 ${ }^{65)}$ ，熱带や曲熱带地方の魚養殖への UV-A 照射の悪影 響 ${ }^{66)}$, 有機除草剂の UV-Bによる分解の評価 ${ }^{67)}$, 紫外線の生物作 用とフリーラジカル68)などが報告された。

植物関連では，UV-Bの影響研究が多く報告された。植物生態 系への成長阻害がオウシュウアカマツ，シラカンバなどについて 閉鎖チャンバーや温公を用いて央験され ${ }^{69)}$ ， セイヨウアブラ十の クロロフィル含量の低下は $\mathrm{CdCl}_{2}$ 処理で押さえられること70), カ ンバ類のフラボノイドと関連物質の蓄積への影響71)，小麦とエン バク繁殖特性は異なり, UV-B 照射は小麦の繁殖効率には影響し ないが, エンバク種子の産量と発芽率が著しく抑制されること72), ブナとトキワガシの葉に対する UV-B 影響の差はフラボノイド 色素の差よりも，形態と構造の差による73)ことなどが明らかにさ れ，針葉樹への UV-B 照射影響のレビュー74)では紫外放射からの 保護機構研究の必要性が強調された。照明学会編のUV と生物産 業75)が刊行された。

$U V$ 殺菌技術 ${ }^{76)}$ については, 製造ラインの UV 殺菌 ${ }^{77)}, U V /$ 光 電子法によるガスと粒子の同時除去による局所空間の超クリーン 化 ${ }^{78)}$ が最近の話題であり, また, 空気清浄とコンタミネーションコ ントロール研究大会で光触媒と UV/光電子法を組み合わせた空 気清浄について多数発表された。水のUV浄化は古くて新しい太 陽エネルギ一利用 ${ }^{79}$, 二酸化千タン光触媒による染色排水の脱 水 ${ }^{80)}$, 饮料水の UV 消毒の性能試験 ${ }^{81)}$ な゙の報告があり, また, 水蒸気の UV スペクトル領域の吸収係数が光音響で測定され た $^{82)}$.

（佐々木政子・東海大学）

\section{参 考 文 献}

(1) 座間，小貫：分光研究 47-3 pp.129-135（1998

(2) Kung, A. H. et al. : Proc. SPIE Int. Soc. Opt. Eng. 3272 pp.100-104 1998

(3) Trickett, R. I. et al. : Opt. Lett. 23-3 pp.189-191 (1998)

(4) Sayama, S. et al. : Opt. Commun. 145-1/6 pp.95-97 (1998)

(5) Bufetov, I. A. : Quantum Electron 28-4 pp.337-339 (1998)

(6) 增田, 久保田：Optronics No.193 pp.87-92 (1998)

(7) Imai, S. and Ito, H : IEEE J Quantum Electron 34-3 pp.573-576 (1998

(8) Potyrailo, R. A. et al. : Anal. Chim. Acta 367-1/3 pp.153-157 (1998)

(9) Haapalinna, A. et al. : Appl. Opt.37-4 pp.729-732 (1998)

(10) Malik, A. et al. : Sens. Actuators A A67-1/3 pp.68-71 (1998)

(11) Carrano, J. C. et al. : Electron Lett. 34-7 pp.692-694 (1998)

(12) Goudjil, K. et al. : Sens. Rev.18-3 pp.176-177 (1998

(13) Matsumoto, S. : Naturwissenschaften 85-3 pp.127-130 (1998)

(14) Munakata, N. : Jpn. J. Cancer Res. 89-3 pp.235-245 (1998)

(15) 恢々木政子：日本香粧品科学会誌 22-2 pp.102-110 (1998)

(16) Leszczynski, K. et al. : Photochem. Photobiol. 67-2 pp.212-221 (1998

(17) 小林邦昭：光アライアンス 9-5 pp.27-31 (1998)

(18) 杉岡, 田代, 和田：Optronics No.193 pp.98-105 (1998)

(19) Jakobs, S. et al. : Appl. Opt. 37-7 pp.1180-1193 (1998)

(20) Rayss, J. et al. : J. Appl. Polym. Sci. 67-11 pp.1913-1923 (1998

(21) Dierking. I. et al. : Liq. Cryst. 24-3 pp.397-406 (1998)

(22) 中山や寸晴：工業材料 46-5 pp.21-27（1998）

(23) Renner, H. : Opt. Lett. 23-2 pp.111-113 (1998)

(24) Nakanishi, M. et al. : Appl. Opt. 37-6 pp.1068-1073 (1998

(25) 松原, 大平, 田中：岐皁県紙榗試験所研究報告 1997 pp.11-14 (1998)

(26) 気象行：報道資料（平成11年 1 月 $20 \mathrm{H}$ )

(27) 気象庁：オゾン観測報告：1997 (平成10年 3 月)

(28) Kane, R. P. Int. : J. Climatol. 18-4 pp.457-472 (1998

(29) Slaper, H. et al. : J. Hazard Mater 61-1/3 pp.77-84 (1998)

(30) Burren, R. et al. : Int. J. Cancer 76-2 pp.201-206 (1998)

(31) Ramaswamy, N. T. et al. : Oncogene 16-11 pp.1501-1505 (1998)

(32) 宮地良樹：日本臨床皮虐科医学会雑誌 No.55 pp.20-23 (1998)

(33) Motoyoshi, K. et al. : Cosmet. Toiletries 113-2 pp.51-56, 58 (1998)

(34) Courtois, S. J. et al. : Biochem. Biopys. Res. Commun. 246-1 pp.64-69 (1998)

(35) 正木1: : Fragr. J. 26-4 pp.18-26 (1998)

(36) 西森康友 : Fragr. J. 26-4 pp.36-42 (1998)

(37) 段野费一郎：Fragr. J. 26-4 pp.11-17 (1998

(38) Kimlin, M. G. et al. : Health Phys. 74-4 pp.429-434 (1998)

(39) 花田勝美：日本香粧品科学誌 $22-1 \quad$ pp.39-42（1998）

(40)幕らしの手帖：74-6/7 pp.5-15 (1998)

(41) 」:出良一：No.55 pp.29-33 (1998)

(42) 岁井, 安抹, 永非, 大藤, 武藤：皮虐科紀要 93-2 pp.161-165（1998

(43) 星川, 野中：西甘本皮虚科 60-2 pp.177-179 (1998)

(44) Urbach F. : Int. J. Toxicol. 17-5 pp.537-540 (1998)

(45) Gonzenbach, H. et al. : Cosmet. Toiletries 113-2 pp.43-49 (1998)

(46) 柴田克已：必須鹈 アミ/酸研究 No.151 pp.28-33 (1998)

(47) 遠藤, 佐々木柱か：照明学会誌 82-11 pp.877-884 (1998)

(48) CIE Standard, S007/E-1998

(49) Miller, S. A., et al. : Photochem. Photobiol. 68-1 pp.63-70 1998

(50) 佐々木一之：皮虚 40-2 pp.105-114 (1998)

（51）佐々木一之：太陽紫外線防御研究委員会学術報告～8-1 pp.69-78 (1998)

(52) 平光忠久：太陽紫外線防御研究委是会学術報告 $8-1$ pp.35-40 (1998)

(53) Linetsky, M. et al. : Arch. Biochem. Biophys. 351-2 pp.180-188 (1998)

(54) Ortwerth, B. J. et al. : Arch. Biochem. Biophys. 351-2 pp.189-196 (1998)

(55) Hardy, S. : Opt. World 26-206 pp.8, 10-11, 14 (1998)

(56) 菅原，野津：太陽紫外線と健康 裳華房(1998.4.20)

(57) 新井ほか：皮膚の老化 工業調查会 (1998)

(58) Yokoyama, S. et al. : FEBS Lett. 423-2 pp.155-158 (1998)

(59) Berrill, M. : ASTM Spec. Tech. Publ. No.1333 pp.21-30 (1998)

(60) Fujiie, A. et al. : Appl. Entomol. Zool. 33-2 pp.263-269 (1998)

(61) Iordanov, M. S. et al. : J. Biol. Chem. 273-25 pp.15794-15803 (1998

(62) Lean, D. R. S. : ASTM Spec. Tech. Publ. No.1333 pp.1-20 (1998)

(63) Hurtubise, R. D. et al. : ASTM Spec. Tech. Publ. No.1333 pp.31-44 (1998)

(64) Kaya, K. et al. : Chem. Res. Toxicol. 11-3 pp.159-163 (1998)

(65) 岡市注：日本海水学会誌 $52-4 \quad$ pp.236-242（1998

(66) Winkler, K. Z. : Emaehrungswiss 37-supplement 1 pp.80-84 (1998)

(67) Schindelin, A. J. et al. : Vom Wasser 90 pp.153-158 (1998)

(68) 伊藤敦汪か：医用衛生紫外線研究会誌 17-1 pp.1-12 (1998)

(69) Huttunen, S. et al. : Chemosphere Chem. Biol. Toxicol. Relat. Environ. Probl. 36-4/5 pp.829-833 (1998)

(70) Larsson, E. H. et al. : J. Exp. Bot. 49-323 pp.1031-1039 (1998) 
(71) Lavola, A. : Tree Physiol. 18-1 pp.53-58 (1998)

(72) Yue, M. et al. : Zhongguo Huanjing Kexue 18-1 pp.68-71 (1998

(73) Paoletti, E. Chemoshere Chem. Biol.Toxicol. Relat. Environ. Probl. 36-4/5 pp.835-840 (1998)

(74) Laakso, K. et al. : Environ. Pollut. 99-3 pp.319-328 1998

(75) 照明学会編：UV と生物産業, 羡賢堂 (1998)

(76) 高倉彰：クリーンテクノロジー 8-7 pp.11-12 (1998)

(77) 向阪信一：防菌防ばい $26-7$ pp.359-370 (1998)
(78) 藤井ほか：工バラ時報 No.180 pp.3-14 (1998

(79) Rolla, T. C. J. : Environ. Health 60-10 pp.30-32 (1998)

（80）原田，田中：工業用水 No.477 pp.11-17 (1998)

(81) Hoyer, O. : Water Supply 16-1/2 pp.424-429 (1998)

(82) Tikhomirov, B. A. et al. : Acta Phys. Sin. Overseas Ed. 7-3 pp.190-195 (1998

\section{2 赤外放射源と作用効果}

赤外センサには, 冷却を要する量子形と非冷却の熱形とがある. 量子形は感度が高く, 熱形は低いというのが通念であった。量子 形センサでの性能の良否はセンサを作るデバイス技術とともに半 導体材料の結晶成長技術に依存している. しかも, 長波長に感度 の高い InSbや HgCdTe などの化合物結晶材料では，2つの技術 的完成度においてシリコン結晶とその LSI 技術に比べ遥かに遅 れている。一方，材料のまったく異なる熱形センサでは，マイク ロマシン加工技術の進歩により 3 次元形状的に素子を微細化して 多素子化，集積化が行えるようになった，量子型の光センサでは 1 画素の面積を小さくすると光量が減少するので, 画像の精細化 と感度向上は相反する条件である。しかし，熱形センサでは， 3 次元的に 1 画素の形状が小形化すると, 熱容量の減少で感度も忍 答速度も向上する，とくに画素の集積化が必要なイメージセンサ では，この効果が如実に現れる。このためマイクロマシン加工技 術の進歩で, 画像精細度も検知能力も量子形に近づいてきた。平 成10年度に㧍ける国内の発表では, 非冷却のイメージセンサが央 用の域に達したことを示している。マイクロマシン技術の忍用は 新たに色々なセンシシングデバイスやシステムの可能性を生み, それが発表されたのが本年の特徵である，以下，量子形，熱形赤 外デバイスについて述べる。

$5 \mu \mathrm{m}$ 帯波長域の赤外センサ材料である InSb 関係では, Si 基板 に成長させた InSbの結晶性"1), さらに $\mathrm{Si}$ 基板上に $\mathrm{Ge}$ アイランド を乗せて結晶の整合性を合わせ InSb をへテロエピタキシャル成 長させる場合の温度特性 ${ }^{2}$, また $\mathrm{Si}$ 基板の上に In $(4 \times 3)$ の再 構成層を乗せ，これに InSbを成長させたもの ${ }^{3)}$, た $\mathrm{Si}$ ともに GaAs 基板に InAsのバッファ一層を介して成長させ, 効果を比較 したものがある ${ }^{4)}$. InSb 関連では InGaAs 系結晶成長を人工衛星 を使って微小重力下で行った報告5がある.

次に長波長赤外用の結晶材では $\operatorname{HgCdTe}$ が最も期待されてい るが，これを成長させる基板として CdTeが適している。この基 板結晶を微小重力下でブリッジマン法で成長させたもの ${ }^{6)}, \exists ウ$ 素ドープ $\mathrm{n}-\mathrm{CdTe}$ を MB 法で成長するもの7)，ホットウオール法 でCdTe，ZnTeの原子層を成長させるもの多がある. CdZnTeも $\mathrm{HgCdTe}$ を成長させる基板として有望視されているが, これを (100) GaAs 基板上に HEW 法で成長させたもの早，MOVPE 法 で成長させた $\mathrm{CdZnTe}$ 層へヨー素ドープを行ったもの ${ }^{10111 な と ゙ ~}$ がある。

$\mathrm{HgCdTe}$ 材料では，プロトンイオンを注入した場合の空孔を評 価したもの ${ }^{12)}$ ，メサ形の $\mathrm{HgCdTe}$ 赤外素子においてディーブレべ ルを評価したもの ${ }^{13)}$, MOCV 法成長による HgCdTe 中のキャリ ヤ濃度制御14)，Si 基板上に同じく $\mathrm{MOCV}$ 法成長を行った $\mathrm{HgCdT}$ 層表面のレーザ顕微鏡観察 ${ }^{15)}$ がある。また $\mathrm{P}-\mathrm{HgCdTe}$ バルク基板を ECR プラズマドライエッチングする場合, 窒素が

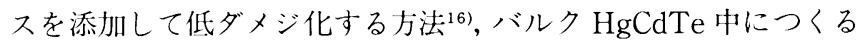
pn 接合深さのイオン注入される元素種類依存性に関する報告 ${ }^{17)}$
がある.変わったものでは, $\mathrm{CdZnTe} / \mathrm{GaAs}$ 基板のうえに $\mathrm{Hg}(\mathrm{Cd}$ $\mathrm{Zn}) \mathrm{Te}$ 層を ISOVPE 法で成長させた報告18), HgCdTe と同じよ うにセンサ材として期待される PbSnTe を微小重力下で行った 場合, 残留重力による対流が結晶の均一性に及ぼす影響を調べた もの帛などがある。

次に非泠却の熱型センサの発展は目覚ましい。誘電ボロメータ 方式のもの ${ }^{20)}$, 高速, 高感度のミリ波用パワーセンサ ${ }^{21}$ に始まり, 1 次元イメージセンサの衛星搭載用焦電型 44 素子 ${ }^{22}, 2$ 次元では PVDF 溥膜焦電型 $16 \times 16$ 素子 ${ }^{23)}$, 自動車搭載用サーモパイル $64 \times$ 32 素子 ${ }^{24)}$, 酸化バナジウムをスパッタしたボロメー夕素子の $256 \times$ 256丽素25)，材料の詳細を明らかにしていないが非冷却の $320 \times$ 240，8 万画素イメージセンサ26)が報告された。また新しいセンサ の芽として，量子井戸効果を利用するものがあるが，MQW 構造 と感度波長, 暗電流の関係 ${ }^{27)}$, 光結合形状と吸収効率の関係をシミ ュレートしたもの28)がある。また, InAs 自己形成量子ドットによ る赤外光の検知 ${ }^{29)}$, 遮断波長が4.7 ミクロンにある室温動作 InAs$\mathrm{Sb} / \mathrm{InAsPSb}$ 赤外七ンサ ${ }^{30)}, \mathrm{Ge}: \mathrm{Ga}$ 遠赤外モノリシック検出 器 ${ }^{311}$ は注目すべきであ万う。また天文観測用に， $4.2 \mathrm{~K}$ レベルのセ ンサとしてショットキー半導体 $\mathrm{pp}^{+}$接合のアクセプタを利用する ものが提案された ${ }^{32)}$. 赤外計測に関するものでは透過波長可変マ イクロ赤外フィル夕年，赤外反射率測定による放射率の算出 ${ }^{34)}$ どが挙げられる。

(白水 俊次・長野工業高等専門学校)

参 考 文 献

（1）平贺：第59[回纫制物理学会学術講演会子稿 $15 \mathrm{p}-\mathrm{YE}-1$

(2) 森ほか：第45回他用物理学会学術講演会予稿 $28 \mathrm{p}-\mathrm{ZL}-4$

(3) 阿阙注加: 第45回㕱用物理学:会学術講演会子稿 $29 \mathrm{p}-\mathrm{ZL}-3$

(4) 荒标注：第59[0]応用物理学会学術講演会子稿 $15 \mathrm{p}-\mathrm{YE}-2$

（5）考野：第59回总用物理学会学術講演会予稿 $17 \mathrm{a}-\mathrm{YM}-8$

(6) 宫武：第59回応用物理学会学術講演会子稿 $17 \mathrm{a}-\mathrm{YM}-7$

(7) 汇部：第59回忍用物理学会学術講演会子稿 $17 \mathrm{a}-\mathrm{YM}-6$

（8）牧野ほか：第45回応用物理学全学術講演会予稿 $28 \mathrm{p}-\mathrm{ZN}-9$

（9）具注第45回応用物理学会学術講演会了稿 $28 \mathrm{p}-\mathrm{ZN}-10$

(10) 浅井注か：第59回応用物理学会学術講演会子稿 $16 \mathrm{p}-\mathrm{YL}-8$

（11）犬飼注か：第59回応用物理学会学術講演会子稿 $16 \mathrm{p}-\mathrm{YL}-9$

(12) 江部は加: 第45回応用物理学会学術講演会了稿 $28 \mathrm{p}-\mathrm{ZN}-15$

(13) 吉野ほか：第45回応用物理学全学術講演会了稿 $28 \mathrm{p}-\mathrm{ZN}-13$

（14）松下ほか：第59回忍用物理学会学術褠演会子稿 $17 \mathrm{a}-\mathrm{YM}-9$

(15) 吉野ほか：第59回応用物理学会学術講演会子稿 $17 \mathrm{a}-\mathrm{YM}-8$

(16) 宮武住：第59回忍用物理学会学術講演会子稿 $17 \mathrm{a}-\mathrm{YM}-7$

(17) 江部注加：第59回応用物理学会学術講演会了稿 $17 \mathrm{a}-\mathrm{YM}-6$

(18) 具汪加：第45回忍用物理学全学術講演会个稿 $28 \mathrm{p}-\mathrm{ZN}-14$

(19) 木下ほか：第45回応用物理学会学術講演会子稿 $29 \mathrm{p}-\mathrm{YN}-5$

(20) 橋本ほか: Tech.Digst.16th Sensor Symposiumu B1-2

(21) 内田ほか：Tech.Digst.16th Sensor Symposiumu B1-4

(22) 石塚注：日本赤外線学会第22问研究会資料 IR-99-4

（23）藤塚注：日本赤外線学会第22回研究会資料 IR-99-2

(24) 应田ほか：日本赤外線学会第22问研究会资料 IR-99-3

(25) 日中ほか：日本赤外線学会第22回研究会資料 IR-99-6

(26) 高橋ほか：日本赤外線学会第 22 回研究会資料 IR-99-5

(27) 西野活加: 第59回応用物理学会学術講演会予稿 $16 \mathrm{p}-\mathrm{S}-8$ 
(28) マサカルほか：第59回灿用物理学会学術講演会子稿 $16 \mathrm{p}-\mathrm{S}-9$

（29）堀口ほか：第59回応用物理学会学術講演会子稿 $17 \mathrm{a}-\mathrm{ZN}-7$

(30) X.Y.Gong ほか：第59回応用物理学会学術講演会子稿 $16 \mathrm{p}-\mathrm{S}-7$

（31）藤原注：第59回応用物理学会学術講演会子稿 $16 \mathrm{p}-\mathrm{S}-11$
(32) ミシャパトラシンほか：第45回匛用物理学会学術講演会子稿 $29 \mathrm{p}-\mathrm{ZL}-10$

(33) 原ほか：Tech.Digst.16th Sensor Symposiumu B1-3

(34) 笹森：日本赤外線学会第22回研究会資料 IR-99-1

\section{3 生物への光放射の応用}

環境庁は，天体観測，動植物などへの影響を防ぎ1)-7)，望ましい 光環境の奏現を計るため,「光害対策ガイドライン」8)-10)を策定し た. 生物への光放射忘用の拡大はうらはらに影響と対策が必要で 女り, 調查, 研究がなされているが, その生理や原理について未だ 不明な点も多く，応用の発展とあわせて今後の解明が必要である。 従来からの農業への忍用については, トルコギキョウ ${ }^{11}$, スイート $ヒ^{0}$ - ${ }^{12)}$, 夏秋ギク ${ }^{13)}$, スプレイギク ${ }^{14)}$ の電照栽培, 電球型监光ラン

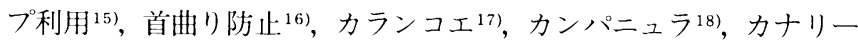
キズタの日長反応 ${ }^{19)}$, 光源・光質を異にしたぺチュニア ${ }^{20)}$, バラの 生長, 日持ち21), 蛍光ランプを利用したスイートピー22)の栽培, マ 一ガレットの穂冷蔵 ${ }^{23)}$, 花壇苗の低温出荷調節 ${ }^{24)}$, 暗室に置いた 27 種のインドアープランツの変化 ${ }^{25}$, LED 利用による花の生育調 節 ${ }^{26)}$ ，について報告された。つぎ野菜ではイチゴの電照栽 培27)28), 連続光補光とナス, ピーマン 29930), 蛍光ランプ補光による

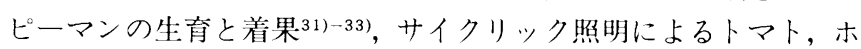
ットペッパーの生䏍 ${ }^{34)}$, 光質に関係してホウレンソウの生長 ${ }^{35)}$,

$\mathrm{F} / \mathrm{Fr}$ による形態制御 ${ }^{36)}$, サニーレタスのアントシアニン合成 ${ }^{37)}$, ビタミン菜のアスコルビン酸含量 ${ }^{38)} キ ュ ウ リ$ 苗と青色光補光 ${ }^{39)}$, イチゴ培養苗 ${ }^{40)}$, トマト接ぎ木苗の LED 補光 ${ }^{411}$ について試験がな され, 弱光販蔵ではチャービル42), トマト ${ }^{43)}$, 十 ${ }^{44)}$, のセル成型 苗について, 光強度とカイワレダイコン ${ }^{45)}$, 貯藏後光照射したホウ レンソウ，コマツ十の品質 ${ }^{46)}$, ホウレンソウの明期と抽苔 ${ }^{47)}$, 光強 度とサツマイモ差し穂の萎调 ${ }^{48}$ について成果が得られた。果樹で はブドウ二期作栽培時の補光 ${ }^{49)-51)}$, ウメの開花と萌芽と補光 ${ }^{52)}$ に ついて実験がなされた．また，オオムギの生長と日長 ${ }^{53)}$, イネの光 合成効率と間欠照射 ${ }^{54)}$, ストロボランプによる個葉の光合成 ${ }^{55)}$, ホ ウレンソウ生葉の紫外レーザによる酸化還元状態の観測 ${ }^{56)}$, ナメ コの光刺激と生体電位 ${ }^{57)}$,の基礎的実験がなされた. 植物工場につ いても多くの展開が見られたが，スウエデポニック植物工場 ${ }^{58)}$ 低 コスト三段野菜工場 ${ }^{59)}, \mathrm{KL}$ 式アグリシステムス ${ }^{60)}$, 立体植物移動 栽培装置 ${ }^{61)}$, 省力化野菜工場 ${ }^{62)}$ な゙゙が紹介された. 閉鎖型苗生産シ ステムについては精力的に研究が進められ ${ }^{63)}$, 組織培養器内環 境 ${ }^{64)-66)}$, トマ卜を対象に生育特性, 苗生産, 電力料金の試算 ${ }^{67) 68)}$, ホウレンソウ苗の抽苔防止 ${ }^{69)}, 3$ 種の植物工場の省エネルギーの 可能性 ${ }^{70)}$, さらに次世代植物工場の展開71) にいてまとめられた. 関連して農業分野への人工光源の忘用 ${ }^{7273)}$ 光放射技術の動向の紹 $介^{74)}$, 植物用メタルハライドランフプ75-77), 無水銀高圧 $\left.{ }^{78}\right)$ 高効率,

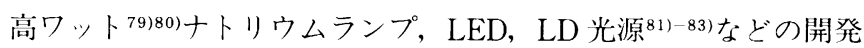
が進められた。 なお, 最近の光利用技術の概要が紹介された ${ }^{84185)}$. 赤外分光による非破壊测定もさまざまな分野に発展しているが, 選果プラントへの導入 ${ }^{86)}$, 食味計の基準統一87), 青果物選別システ ムの動向 ${ }^{88)}$, 糖, 脂肪などの体内成分に関連してメロン ${ }^{89990)}$, 夕゙イ

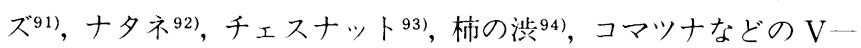
$\mathrm{C}^{95}$, サラダナの生理障害 ${ }^{96)}$ 判定残留農薬 ${ }^{97)}$, 血卵の検出 ${ }^{98799)}$, 乳 牛の栄養状態100), 個体識別 ${ }^{1011102)}$, LIF 法による樹木の生育診 断103)など多くの成果が得られている.UVに関連して農作 物 ${ }^{104)-106)}$, 微生物 ${ }^{107)}$, 海洋生物 ${ }^{108)}$, ウ二 ${ }^{109)}$, 藻類への影響110)111), 野菜, 果樹の青色光とUV 吸収 ${ }^{112)}, 7$ 種の花・野菜の胚軸徒長抑

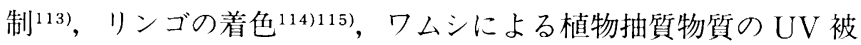
害抑制検定 ${ }^{116)}$, アオコ ${ }^{117)}$, 養液殺菌 ${ }^{118)}$, 河川 ${ }^{119)}$, 多ムの浄化 ${ }^{120)}$, 作物生産 ${ }^{1211}$, 水産への UV 応用が報告され ${ }^{122)}$, 遺伝生態研究の展 望 ${ }^{123)}, \mathrm{UV}$ と生物産業 ${ }^{124)}$ についての単行本が出版された。

次に，光利用による病害防除 ${ }^{125)}$ に関連して，ブドウ枝膨病 ${ }^{126)}$, シバ葉腐病 ${ }^{127)}$, 赤色光による病害抵抗性の誘導 ${ }^{128)}$, について報告 された。また, カメムシの発生予察と防除 ${ }^{129) 130)}$, 黄色営光灯によ る夜蛾, 夕バコ蛾, 夜盗虫の防除131-134), キクの電照栽培への影 響 ${ }^{135)}$, 光と蚊 ${ }^{136)}$, 蚊の誘殺器の開発 ${ }^{137)}$, 光触媒処理・防虫コーテ イング装置付き照明器具の試作 $\left.{ }^{138}\right)$ が行われ, ミカン黄色アザミウ

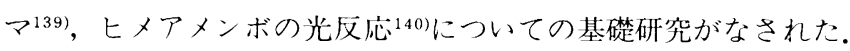
また, 投光法による豚の体高測定 ${ }^{141)}$, 水産関係ではマダイの周年 採卵 ${ }^{142)}$ 七ラメの黑化 ${ }^{143)}$, 集魚灯技術の課題 ${ }^{144) 145)}$, マアジの䬹選

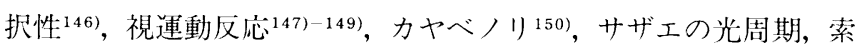
慨日週性 ${ }^{151)}$, 微少藻類の高密度培養 ${ }^{152)-156)}$, に関して多くの成果 が得られている.

（㝨原善和・新日本気象海洋(侏)）

\section{参 考 文 献}

\footnotetext{
（1）高尾保之：農水省野菜茶試研究会資料 pp.37-43 (1998)

(2) 高尾保之：園学誌 67-5 pp.778-784 (1998)

(3) 原田皓二：農業関係試験研究成果 pp.37-38 (1998)

(4) 福阔県農業技術課 普及資料581 pp.112-114（1998)

(5) 森由, 洞口：電設学会誌 18-11 pp.777-784 (1998)

(6) 田澤信二：照学関西講習会集 pp.22-35 (1998)

（7）岩崎電気(侏） RL-1 p.11（1998）

(8) 環境庁”光售对策ガイドライン p.100 (1998)

(9) 川上幸二：照学誌 82-6 pp.408-412 (1998)

(10) 安彦健夫：照学関西講習会集 pp.14-21 (1998)

(11) 渡辽, 兼武：澋学誌 67 (別 2 ) p.625 (1998)

(12) Atsugi, Inoue Higuchi Suppl. J. Jap. Hort.. : 67-1, pp.226 (1998

(13) 谷川, 松井, 小林：溑学誌 67 (別 2) p.623 (1998)

(14) 大保, 石田：固学誌 67 (別 2) p.623 (1998)

(15) 洞口ほか：31回照学全大 pp.273-274（1998）

(16) 谷川孝弘：農耕と固芸 53-11 pp.122-126（1998）

(17) Amaki, Ookawara, Higuchi : Supl. J. Jap. Hort. 67-1, pp.272 1998

(18) 勝谷, 梶原：園学誌 67 (別 2) p.414 (1998)

(19) Al-Juboory, et. al : HortScience 33 pp.237-239 (1998)

(20) 吉中ほか：園学誌 67 (別 2) p.384 (1998)

(21) Mortensen, et. al : Sci. Hort 737 pp.229-237 (1998)

(22) Inoue et. al : Suppl. J. Jap. Hort. 67-1 p.265 (1998)

(23) 稲葉, 堀内: 園学誌 67 (別 2) p.415 (1998)

(24) 島, 本田：農業電化 51-10 pp.26-30 (1998)

(25) Kobayas, Suzuki, Higuchii : Suppl. J. Jap. Hort. 67-1, p.233 (1998)

(26) 藤風政二：農及園 $73-2 \quad$ pp. $53-58$ (1998)

(27) 鹿野弘、: 農耕と園芸 53-12 pp.146-147 (1998)

(28) 西山, 大川：图学誌 67 (別 2) p.519 (1998)

(29) 栘田以か：園学誌（別 2) p.310（1998）

(30) 川口, 吉田, 桝田：園学誌 (別 2) p.311 (1998)

(31) 桝田, Murage：園学誌 67-6 pp.862-865 (1998)

(32) 桝田ほか : Suppl. J. Jap. Hort p.203 (1998)

(33) 渡道慎一：施設と園芸 103 p.41 (1998)

(34) Chi SungHan et.al : Jour. Korean. Soc. Hort. 39-3, pp.233-237 (1998)

(35) 羽生, 庄子：農気・生環・施設要旨 pp.382-383 (1998)

(36) 村上克介：照学公開研 AR30-35 pp.25-28（1998）

(37) 掋子, 羽生：農気・生環・施設要旨 pp.384-385 (1998)

(38) 清田ほか：農気・生環・施設要旨 pp.396-397(1998)

(39) Sung, I. et.al : 生環調節 36-2 pp.85-90 (1998)
} 
(40) Tanaka et.al : Suppl. J. Jap. Hort. p.213 (1998)

(41) 小島ほか：植物工場大要旨 24-25 pp.24-25 (1998

(42) 葍土原, 高久, 飯本: 農気・生環・施設要旨 pp.244-245 (1998)

(43) 富上:原, 磯部, 飯本: 農気・生環・施設要旨 pp.242-243 (1998)

(44) 宮丸ほか：植物工場大要旨 pp.22-23（1998

(45) 木村注か：園学誌 67 (別 2 ) p.312 (1998)

(46) 龺, 增田, 山脇：園学誌 67(別 2) p.482 (1998)

(47) 全ほか：農気・生環・施設要旨 pp.214-215 (1998)

(48) 古在活加：農気・生環・施設要旨 pp.210-211 (1998)

(49) 小野ほか：園学誌 67(別 2) p.228（1998

(50) Kubota et. al. : Suppl. J. Jap. Hort. p.76 (1998)

(51) 洞口注：31照学全大 pp.269-270（1998）

(52) 高松, 田中, 宇都言：農気・生環・施設要旨 pp.398-399 (1998)

(53) 玉置, 猪谷, 後藤：日作記 67 (別 2 ) pp.124-125 (1998)

(54) 西村汪か：日作記 67 (別 1) pp.102-103 (1998)

(55) 今井, 赤坂：農気・生環・施没要旨 pp.328-329(1998)

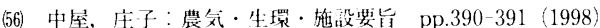

(57) 高橋ほか：植物1場大要旨 pp.86-87 (1998)

(58) 須永昌博：植物：場大要旨 pp.46-47（1998）

(59) 農電協北陸支部：農業电化 51-2 pp.28-29 (1998)

(60) 田本均：植物 I場大要旨 pp. 7 -9 (1998)

（61）堀部，松川小，持罩：植物工場大要旨 pp.102-103 (1998)

(62) 中原，北原，山嵛：植物工場大要旨 pp.80-81 (1998)

(63) 金子, 啮行, 计在：楠物.J場大要旨 pp.48-49 (1998)

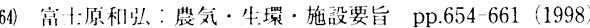

(65) 鈴木，全，吉在：植物厂場大要旨 pp.52-53 (1998)

(66) 渋谷，金子，证在：植物工塨大要旨 pp.54-55 (1998

(67) 大l1，金子，古在：植物工場大要旨 pp.50-51 (1998)

(68) 大川ll, 占在：植物工場学会誌 10-2 pp.96-107 (1998

9) 全注加：植物门場大要旨 pp. 56 -57(1998

10)阔野活か：農気・生環・施設要旨 pp.284-285 (1998)

）植物丁場学会：次世代植物工場の展開 p.77（1998

田澤信二：農業電化 51-9 pp.9-13 (1998)

田澤信二：農業電化 51-11 pp.8-12（1998）

河本康太郎：照学公開研 AR-35 pp.1-5 (1998

村上ほか：植物工場大要旨 pp.32-33 (1998)

本多ほか：植物工場大要旨 pp.34-35（1998

中村䚾：植物工場大要旨 pp.36-37 (1998)

村上，斉藤，洞口：31照学全大 p.268（1998）

稻堭活加：植物工場大要旨 pp.28-29(1998)

稻坦ほか：植物工場大要旨 pp.30-31 (1998)

森, 高辻：植物工場大要旨 pp.26-27（1998

柳, 西応: 農気・生壦・施没要旨 pp.326-327 (1998)

山崎活力：園学誌 67 (別 2 ) p.313（1998）

岡野利明：農業龟化 51-9 pp.2-8(1998)

5) 福田自也：ハイドロポニックス 11-2 p.71 (1998)

6) 前田柘：農気・生環・施没装旨 pp.670-673 (1998)

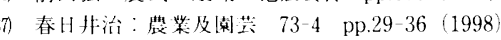

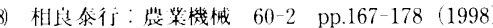

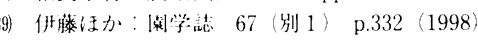

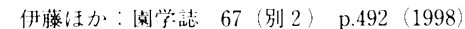

河野，仾像，本閣：溒学誌 67 (別 2) p.491 (1998)

作滕注か：日作記 67 (別 1) pp.26-27 (1998)

3) Saito et. al. : Suppl. j. jap. Hort. p.83

(94) 伊藤茂: 農業及阁芸 $73-2$ pp.59-62 (1998)

(95) 小陏，志贺，斉滕：農気・生環 - 施設要旨 pp.526-527(1998

(96) 小易活か：植物工場大要旨 pp.136-137 (1998)

7 伊解, 河野：固学誌 67 (別 2) p.490 (1998

8) 中野, 水谷, 大眆：農業施設 29-3 pp.117-123 (1998
(99) 赤羽根ほか：農気・生環・施設大要旨 pp.522-523（1998

(100) 陳ほか：農気・生環・施設大要旨 pp.524-525(1998

(4in) Tsenkova et. al. : 農気 - 生環 - 施設大要旨 pp.524-525 (1998

(102) Tsenkova et. al. : 農気·生環·施設大要旨 pp.518-519 (1998)

(10)佐川, 峰内, 高橋: 農気・生環・施設大要旨 pp.336-337(1998)

(64) 物部, 日出間, 熊谷：東北大 IGE-24 pp.179-181 (1998)

(115) 菅沼浩敏：農業電化 51-11 pp.2-7 (1998)

(1166) 前川，佐藤，熊谷：東北大 IGE-24 pp.182-184（1998)

(107) 本田, 内藤, 熊谷：東北大 IGE-24 pp.158-159 (1998)

(108) 矢部和夫：日水学秋要旨 p.123 (1998)

(109) 矢部ほか：日水学誌 64-4 pp.606-609 (1998

(1:10) 長島, 高橋, 井上：藻類 $46-1$ p.85 (1998)

(III) 矢部，牧野：藻類 64-1 p.85 (1998)

(1i2) Baur, P. et. al. : Gartennbauwissenschaft 63-4 pp.145-152 (1998)

(113) 裴ほか：園学誌 67-6 pp.945-950（1998）

(114) Kataoka, Sugiyama, Beppu : Suppl. J. Jap. Hort p.73 (1998)

(115) Wang, Arakawa : Suppl. J. Jap. Hort. p.120 (1998)

(116) 宇城正和：H水学春要旨 p.117 (1998

(11ii) 院多本, 前川：莀業施没 29-2 pp.51-56 (1998)

(iil) 高橋, 高屋, 正森：济学誌 67 (別 2) p.382 (1998)

(119) 岩崎, 小野, 木下：31照学全大 p.67 (1998)

（20) 藤田，服部，中烏：夕厶技術 147 pp.57-65 (1998)

(12) 熊谷忠：束北大 IGE-24 pp.29-43 (1998)

(122) 苦沼浩䰻：農業電化 51-11 pp.2-7 (1998

(123) 胡月䑤之：水産增殖 46-4 pp.621-622 (1998)

(124) 照明学会：UV と生物産業 養賢堂 p.231 (1998)

(15) 本田雄一：日植病報 64 pp.232-234 (1998)

(126) 田代, 井出, 衛藤：日植病報 64-6 p.587 (1998)

(122) 伯野, 副島, 久能：日植病報 64-6 p.632 (1998)

(182) 梅津, Islam, 本田：日植病報 64-6 p.622 (1998

(129) 大平喜男：果樹日本 53-4 pp.22-25 (1998)

(130) 桑澤久仁厚：果樹日本 $53-5$ pp.50-53 (1998)

(13) 島嘉輝：園学誌（別 2) p.552 (1998)

(132) 山中正仁：農耕之園芸 53-6 pp.140-143 (1998

(193) 数哲男：農業電化 51-10 pp.22-25（1998）

(134) 中寺注加：42応動昆大 p.1013 (1998)

(1.55) 石倉, 向阪, 福島：植物工場大要旨 pp.82-83 (1998)

(j3) 真喜屋清：ヒトスジシマカ形態'真集 九人出㸡会 p.87(1998)

(a) 渡傻, 浅野, 岩尾：農業電化 51-10 pp.19-21 (1998)

(198) 大井, 堀越：31照学全大 pp.277-278（1998）

(199) 嶋田知英：42応動昆大 p.1105 (1998)

(14) 森岡，原田：42応動昆大 p.115(1998)

(iil) 皆川, 都築：宸気・生環・施設要旨 pp.298-299 (1998)

(16) 近畿大水库研：農業㲠化 51-7 pp.19-23（1998）

(14) Iwata, Kikuchi : Environ. Bio. Fishers 52 pp.291-297 (1998)

(Iii) 有元貫文: H水大秋要旨 p.208(1998)

(16) 崔注か：日水誌 64-4 pp.650-657 (1998)

(116) 古源, 福日：水产增殖 46-4 pp.591-592 (1998)

(4ii) 段行川英- - : [水誌 644 pp.626-630 (1998)

(48) 高川，稻田，渡部：H水誌 64-6 pp.631-635 (1998)

(149) 滕田注か：日水大秋要旨 p.6(1998)

(150) 管下ほか：藻類 46-1 p.94 (1998)

(151) 平田, 松岡, 新納：日水大秋要旨 p.50(1998)

(152) 奥村ほか：日水大秋要旨 p.118（1998）

(153) 中島汪か：日水大春要旨 p.119（1998）

(15i）洞口公俊：照学公開研 AR-35 pp.29-34 (1998)

(155) 洞口ほか：31照学全大 pp.271-272（1998）

(156) 村上ほか：農気・生環・施設要旨 pp.286-287(1998)

\section{4 生体・医療への光放射の応用}

眼底検査は眼科の日常診療で, ほとんど全部の症例に用いられ るといってよいほど必要な検査法である.

この検査で全身的な変化を直接観察することができる，糖尿病 の病変の程度や, 動脈硬化や血圧などの程度の判定に大きな力を 発揮する。

ただ, 細胞レベルの病理組織を採ることは眼底に関しては難し い.そこで, 光学的干渉断層計で眼底の診断像を得ようという試 みがされている。
光学的干渉断層計 (optical coherence tomography=OCT) の 原理は，超音波診断装置の原理に似ている。OCTでは超音波の代 わりに近赤外低干涉ビーム $(850 \mathrm{~nm})$ を用いて, 眼底の断層像を得 ようというものだ.

コントロール波と測定光として眼内に入った光は, 眼底の各層 で反射して戻ってくる．この反射光の時間差を持った光とコント ロール波を合流すると干渉現象が生じる。この干渉現象を空間位 置関係に換算すると断層像ができる ${ }^{112)}$. 
この診断法は短時間で非侵襲的検査法なもので，今まで得られな かった情報が得られるという革命的検査法であることから，改良が 加えられると数年後には普及してルーチンの検査法になるだろう。

化粧品業界においては，古くは製品の色調を管理するためや， 処方された試作品の色調を管理寸るためにカラーコンピュー夕が 用いられた。

最近はメーキャップの仕上がりが個々のユーザの望む色調にな っているかどうかを判断する測定機器の開発が試みられている.

人間の皮䖉色は多層の組織の結合された色調であり，そのうえ に相乗に化粧品を置くことが，メ一キャップであり，その成分も 吸収，反射，拡散と複雑な光特性をもった物質からなっている。

直角方向からの色調を, 入射角を変えた光を照射した場合では, 色調は変わってくる。このようなことを，人間の眼はすべて判読 してメーキャップを見ている.

これらの問題を色調測定器を用いながら，皮䖉の光特性をふま えた光学的方法でメーキャップ製品の選択の測定方法を提案し ている3)

光防御に関守る最近の知見は, 第20回日本光医学・光生物学の シンポジウム「紫外線防御法とその特性」で集約されている.

ガラス・フィルムによる遮断効果, 最近流行の紫外放射防御衣 類, サンスクリーン剂の処方と効能, 効果, 正しい選択について, また, 樍極的な表皮の光防御能を高める方法として, サンタンニ ングを中心に MSHの局所注射なども論じられている(4)-7).

積極的に生態の防御能をたかめる試みは盛んに行われている。 光による光老化を防ぐためにビタミン A 酸とグルクロン酸を投 与し，それをサイトカインの変化と遺伝情報の変化を指標にして 観察し, ビタミン A 酸とグルクロン酸が紫外放射防御と老化を防 ぐことに役立つことが報告されている8 .

UVA サンスクリーン剂の効能効果の判定には, オクソラレン ローションを外用し，その部位にUVAを照射するとそここに生じ る紅斑㪀応と色素沈着の阻害を指標としたものが一般的に再現性 がよいので使われている.

この方法によると試験部位に 1 年余におよぶ色素沈着を残すの で嫌われている。

代替法とし IPD が用いられたり，そのほかのUVAを作用波長 とする物質を使用したりしているが，再現性が悪い.

徳永らはトランスポア・サージカルテープにUVAサンスクリー ン剤を塗布して, リボフラビン, ニトロブルーテトラリゾリウム,
メチオニンの混合液から UVA 照射によって作られるブルーホル マザンを測定するという方法で，UVA サンスクリーン剂の効能 効果を判定する代替法を報告している.

ここ数年はアレキサンドライト・レーザーを使ったレ一ザー脱毛 が形成外科医，皮䖉科医によって行われるようになり，それを主要な 業務とする脱毛クリニックができるようになり盛業であるという。

ただ，今後，この種のクリニックが多くなると業として成立す るかどうかは問題であるが，すでに，レーザ一脱毛という言葉に まどわされて，正しいレーザー光源を使わないクリニックで治療 を受けて永久脱毛でなかったというトラブルが発生している.

確かに，アレキサンドライト・レーザーを使っても，数力月後 に毛の再生を20３0\%位みとめることがあり，数回の処置が必要 になる。

しかし，ほかのレーザーでも脱毛は起こせるし数力月の脱毛期 間はあるので，そのことを相互に理解していればトラブルにはな らないであろうが，レーザー脱毛ということでの誤解は多い.

また，正しくない機器をエステティックサロンなどに売ってい る業者导ある。

一方，従来，いろいろ問題のあった電気脱毛はレーザー脱毛に 取って代わられる傾向にある。レーザ一脱毛は形成外科医，皮膚 科医が主に行っているので，電気脱毛も医師によって行われてい るところのみが残りそうで，エステティックサロンで美容脱毛と 呼ぶ電気脱毛を高額な料金で受ける人は，経済的要因も絡んで少 なくなってきている10111).

今後はレー-ザ一脱毛の正しい実施を広げていくことと，不適切 なレーザー機器の使用は厳重に監視しなければならない。

（戸田＼cjkstart淨・戸田皮膚科クリニック）
(1) 岸章治：OPTNEWS $106 \quad$ p.26 (1998)
(2) 大谷倫裕注加: 臨眼 52 p.27 (1998)
(3) 中村直生：J. Soc. Cosmet. Chem. Japan 32 p.233 (1998)
(4) 河本康太郎：第20回日本光医学. 光生物学会 p.33 (1998)
(5) 恢藤健二: : 间 上: p.33 1998
(6) 川田暁：同上 p.34 (1998)
(7) 船橋洋子: 间 上: p.34 (1998)
(8) Wang, Z. O. et al. J. Invest. Dermatol. 110 p.490 (1998)
(9) 德永裕司汪か: J. Soc. Cosmet. Chem. Japan 32 p.287 (1998)
(10) 大城俊夫：レーザ一治療に上る安心脱毛 東日書院 東京 (1998)
(11) 万䧃浮：Skin Biology Copsule \& Comment 1 p.8 (1998)

\section{5 オプトエレクトロニクス}

\subsection{1 総括的動向}

オプトエレクトロニクス〈光子（フォトン）と電子, 光とエレ クトロニクスを結ぶ士学の一分野. 光エレクトロニクスともいう. 半導体による発光素子 (LED など), 光・電気変換素子, 各種レー ザー，各種光学材料・素子などと，それらの応用装置が含まれる.> を基盤技術とする産業（いわゆる“光産業”）は，日本国内の総生 産高が，1981年以来昨年までの18年間，年率平均 $20 \%$ 以上の伸張 率で成長を続け, 昨年には 5 兆円以上の規模となり, 照明産業(昨 年の総生産高：約 1 兆円）を遙かに淩駕する規模となっている. そして，今年以降も同等以上の成長率が見込まれている.

この光産業の活性ある状況を受けて，オプトエレクトロニクス 分野においても, 新製品・新技術の開発が相次ぎ, 活性ある状況 となっており1)，1998年 5 月 3 日から 5 月 8 日までの期間開催さ
れた CLEO'98（第13回レーザーと電子光学に関する年次会議）に おいても, 高エネルギー物理から通信, 薬学, 光コンピューター にいたる幅広い分野に，数多くの研究成果が発表され，活発な議 論が展開された2).

以下に，主要項目別に1998年の技術動向を述べる.

\subsection{2 光源, 発光素子}

オプトエレクトロニクスの関連光源・発光素子としては，LED

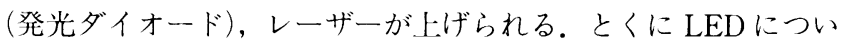
ては，オプトエレクトロニクス関連装置用としてのほか，電気一 光エネルギー変換効率のよい点が注目され，一般照明用を含む視 覚支援関連や光エネルギーシステム用の光源としての利用の可能 性が検討されている(3)-6). 
LED が白熱電球や蛍光ランプに互して一般照明用光源として 使用されうるかどうかは，今後の重要課題であるが，一般照明用 以外の視鸴支援関連や光エネルギー利用の面では，すでに広く実 用されている分野も多い. 交通信号やディスプレイ関連7)-9), 植物

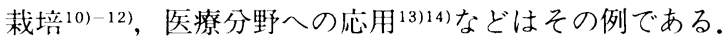

オプトエレクトロニクス関連光源では, 青色光波長域 $(400 \mathrm{~nm}$ ～500nm）に発光を持つ光源の性能向上が大きな課題であるが， LED, レーザー, ほか各種の光源・発光素子において多くの進展 が見られた ${ }^{15)-20)}$. また, レーザーについては, 垂直共振器を組み 合わせた面発光レーザーが研究されており ${ }^{211}$, 将来のレーザーの 応用分野の拡大が期待されている.

LED, レーザー以外の関連光源・発光素子についても, 低消費 電力で, 光束の大きいモバイル機器に適した液晶ディスプレイ・ バックライト用冷㓌極蛍光ランプ221, 分子分散形高効率有機 $\mathrm{EL}^{23)}$, 化学:発光を利用した無排熱光源の開発24)25)や, 监光体などの ルミネセンス材料の量子効率改良の研究26)-29)なども推進された。

\subsection{3 オプトエレクトロニクス・デバイス}

1998年のオプトエレクトロニクス・デバイスの技術開発の動问 としては，次の 3 点が上げられる ${ }^{30)}$.

(1)高機能の光・電子デバイスを低価格で提供し，光技術を使用 者側へ拡大寸ることをねらいとした研究が活発化している.

(2)波長多重光技術を利用した光ネットワークの構想が明確にな り, 光源, 増幅器, 光ファイバー, 受光回路などを中心とした デバイス開発が急速に進展している。

(3)全光形波長変換技術, 超短パルス光を利用した全光信号処理 技術など，実用を念頭においた次世代システム開発のためのブ レークスルーを模索する研究が継続されている.

一例としては, 画像処理の際の光のバラツキを補償する方法 ${ }^{31)}$, 多重量子井戸形変調器に基づいた新しい構想のVLSI ${ }^{32}$, 電飾照 明装置用の自動調光システム吕などが上げられる.また, 光エレク トロニクス材料や光学被覆技術についても新しい技術開発の成果 が見られた ${ }^{3435)}$.

\subsection{4 オプトエレクトロニクスの応用技術}

光産業の年率平均 $20 \%$ 以上の伸張を支えているのは, 毎年多数 開発される新しい応用技術である１998年も，前年までと同様， 多くの開発の成果が発表された。具体的なものとしては，デジ夕

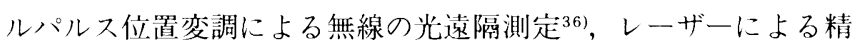
密プレス部品の表面欠陥検出技術 ${ }^{37)}$, LED を利用した三次元空間 における遠隔操作マイクロハンド38)，ホログラフィーなどを利用 した干渉計39)-42)などが注目される。

（河本 康太郎・社)日本電球工業会）

\section{参 考 文 献}

(1) Irakliotis, L. J., Mitkas, P. A. : Computer 31-2 pp.36-37 (1998)

(2) Noble, M., Kunts, D. W. : Laser Focus World 34-5 pp.109-121 (1998)

(3) 板束：月刊ディスプレイ 11-3 pp.1-7 (1997)

(4) Debray, A., Hoehn, K. : SIEMENS COMPONENTS 36-5 pp.20-21 (1998)

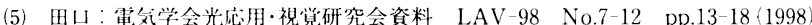

(6) Heeger, A. J. : Solid State Communication 107-11 pp.673-679 (1998)

(7) 金子：月刊ディスプレイ 11-3 pp.8-12〈1997〉

(8) 内野：月刊ディスプレイ 11-3 pp.13-17 (1997)

(9) 時本：月刊ディスプレイ 11 -3

(10) 渡辽：月刊ディスブレイ 11 -3 pp.43-48 (1997)

(11) 中村：レーザー研究 25-12 pp.850-854 (1997)

(12) 西用, 山中：レーザー研究 25-12 pp.845-849 (1997)

(13) 木下：月刊ディスプレイ 11-3 pp.49-55(1997)

(14) 阙本：月刊ディスプレイ $11-3$ pp.56-64(1997)

(15) 中村：セラミックス 33-5 pp.353-356（1998)

(16) 阙崎，中村，枺：電子技術 40-9 pp.57-62 (1998)

(17) Webjoern, J., Waarts, R. G. : Laser Focus World 34-5 pp.135-142 (1998

(18) Zheng, H., Zhang, R., Wu, Y., Shen, J. : Chemical Letter No.9 pp.909910 (1998)

(19) Cao, H., Gao, X. C., Zhai, J., Huang, C. H. : Synthetic Metal 96-3 p. $191(1998)$

(20)石橋：国際つォーラム「映像の明日をひらく肖华発光」资料 pp.25-32〈1996

(21) Gulden, K., Eitel, S., Jeggle, D., Moser, M., Riel, P. : Conference Proceedings ofInternational LEOS Annual Meetings 10-2 pp.15-16 (1998

(22) 西村, 筒井：電子材料 6 月昂別冊 pp.56-58 (1998)

(23) 長友, III I : 電気学会光忍用 - 視觉研究会资料 LAV - 98 7-12 (1998)

(24) 石井, 袷比：化学工学会秋期大会研究発表洋演要旨集 31 st No.63 (1998)

(25) 石井, 非下: 化学工学会秋期大会研究発表洋演要旨集 31st No.64 (1998)

(26) Akiyama, M., Xu, C.N., Nonaka, K., Watanabe, T. : Applied Physics Letter 73-21 pp.3046-3048 (1998)

(27) 小南：電子情報通信学会技術研究報告９8-396 pp.13-17 (1998)

(28) Shpinkov, I.N., Kamenskikh, I.A., Kolobanov, V.N., Mikhailin, V.V Vasilev, A.N., Kirm, M., Zimmerper, G. : Physics Status Solid 170-1 pp.167-173 (1998)

(29) Burin, A.L., Ratner, M.A. : J Chem Phys 109-14 pp.6092-6102 (1998)

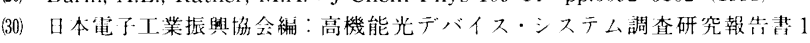
(1998)

(31) 岮本：自動化技術 30-11 pp.16-19 (1998

(32) Lentine, A.L. : Conference Proceedings of International LEOS Annual Meetings 10-2 pp.83-85 (1998)

(33) 中四，高原，河井，浜田：香川県、棠技術センタ一研究報告 No.4（1997）

(34) 松丸：JETI, 46-12 pp.108-109（1998)

(35) Simpson, J., Lewis, K.L. : Proceedings of Annual Technical Conference of Society of Vacuum Coaters 40th pp.248-254 (1998)

(36) Otte, R., De Jong, L.P., Van Roermund, A.H.M. : IEEE Trans Instrument Meas $47-1$ pp.51-55 (1998)

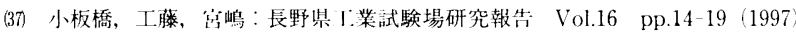

(38) Khamesee, M.B., Kato, N., Nomura, Y., Mizutani, K., Nakamura, T. Robot1998 pp.321-327 (1998)

(39) Dixon, G.J. : Laser Focus World 34-3 pp.107-108 (1998)

(40) Yuan, L. : Optical Laser Technology 29-7 pp.365-369 (1998)

(41) 野崎：Konica Technical Report Vol.11 pp.27-30 (1998)

(42) Wang, Q., Ning, Y.N., Grattan, K.T.V., Palmer, A.W. : Optical Laser Technology 29-7 pp.371-376 (1998)

\section{6 印写工学・工業への光放射の応用}

光放射の工業への忍用では, 硬化技術をはじめ多くの分野で展 開がされているが，「環境」や「省エネルギー」をテーマにかかげ た報告が多くなっている，とくに多オキシンに代表される有機 塩素系化合物の環境に及ぼす影響などが大きく取り上げられ，そ の分解処理に関する試験が水中, 気相中で多く実施され発表され た. たとえば, 埋め立て地の浸出水で問題となったトリクロロエ チレン (TCE), ジクロロメタン, テトラクロロエチレン (PCE) やダイオキシンなどの土䁃活染物質をUV(紫外放射)によって分
解する技術であるが，UV 単独よりオゾンや過酸化水素などの酸 化剂と併用する AOP 法 (Advanced oxidation process) と呼ば れる促進酸化法の方が処理効果が高いといった報告が数多くされ

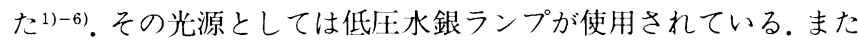
気相中では光触媒とブラックライトとの組み合わせによる処理報 告もされている7)-9).

印刷やコンバーテックの分野では，悪臭防止法やVOC 規制か ら塗料の無溶剂化が求められ, 無溶剂樹脂で硬化させることが可 
能な UVや $\mathrm{EB}$ (電子線)による硬化技術が環境問題の解決につな がるクリーンなシステムとしてあらためて注目されてきている。 この分野では市場が変化して扔り，水回りの壁材や，光ディスク や液晶ディスプレイ用接着剂, 剝離用リリースコーティング，レ ンズコーティングなどこれまでになかった新しいマーケットが開 けつつあり，とくに木工用塗料の分野では，急激な伸びが見られ た ${ }^{10)}$.この分野では，ラドテック研究会（旧名 UV/EB 表面加工 委員会) が活発に活動し，年報がまとめられている ${ }^{11}$ 。雑誌「ポリ ファイル」は毎年 2 月号で特集が組まれ1998年度も，アプリケー ション，樹脂や染料，装置に対する技術動向が紹介12)された.

そのなかで UV 樹脂や塗料の動向として，カチオン重合系樹脂 が午コーティングを中心に本格的に展開されはじめていると紹介 されている。従来のラジカル重合系樹脂と異なり，モノマ一の刺 激参がなく，塗膜への密着性がよいこと，収縮が小さいこと，高 速硬化性に優れているなどの特長があげられている。また逆に， モノマー,オリゴマーの種類が少ないことや光重合開始剂も高価 で数が少ないことが問題であった。しかし，近年モノマーにオキ セタン化合物が光重合開始剤にボロン系化合物がそれぞれ開発さ れフォーミレーションの幅が出てきている ${ }^{13)-16}$. 具体的にUV力 チオン硬化型剝離紙用シリコーンの紹介 ${ }^{17}$ もされている。 さらに UVインキは，機能性を付与するインキの開発や実用化が進めら れている18).

UV の利用は, 前述の利用以外に, 最近ではマルチメディア時代 の到来にともなって，半導体の高度集積化や液晶ディスプレイの 大型化，記憶媒体（光ディスク）の大容量化に対応して新光源に よるリソグラフィや精密洗浄，貼り合わせなど新しい技術が登場 して普及しつつある ${ }^{19)-28)}$. 光造形に対しても照射方法の検討など の動向が紹介(29)-31)されている.

$\mathrm{EB}$ に関しては，1998年12月 8 日〜10日に東京ビックサイトに て「第23回日本アイソトープ・放射線総合会議」が開催され，そ のなかで種々のアプリケーションや装置動向が発表された ${ }^{32} . \mathrm{EB}$ は装置の小型化がクローズアップされてきている，とくに加速電 压が $100 \mathrm{kV}$ 以下でコンパクトで安価な装置として薄膜処理に効 果的として提案がされた ${ }^{33)-36)}$.

殺菌・滅菌の分野でも UV $\mathrm{EB} の$ 利用検討も進められた。 UV ではオゾンと併用して浴用水中のレジオネラ菌を良好に殺菌した 例 ${ }^{37} や$ 包装技術分野に対しても UV・EB の殺菌効果に関して装置 と事例が紹介淿是された。

また，EBの硬化技術を使用して抗菌抗力ビ性付与した技術と 照射での殺菌効果も合わせて形で，EBの殺菌加工として紹介 ${ }^{39}$ されている。

耐候試験機関係にも光放射が応用されている。この分野では， マテリアルライフ学会で研究発表が行われ，とくにキセノンアー
クランプによる促進耐候試験関係の報告が多くされた ${ }^{40)-43)}$.

以上のと揖り，印写工学・工業への光放射の応用は，環境問題 を考えたクリーンな処理として，展開が進められたことが感じら れ，今後はさらに実用の装置として，より身近になりそうである.

(木下 忍・岩崎電気(侏)

\section{参 考 文 献}

（1）穴田, 小坂, 山田, 松井：第33回日本水環境学会 p.74 (1998)

（2）鳥羽儿，西村，須藤，稻森：第33回日本水環境学会 p.76（1998）

（3）平田, 北見, 石井, 常田：第33回日本水環境学会 p.80 (1998)

（4）葛, 二見, 中川, 田中, 伊藤：用水と廃水 $40-7$ pp.24-28（1998)

(5) 舩石，関：環境技術 27-5 pp.21-25（1998）

（6）松谷, 橋本 (光), 橋本 (正)：水環境学会誌 21-1 pp.29-34 (1998)

（7）金宗，伊藤，村林，塩沢，岡村：第33回日本水環境学会 p.79 (1998)

(8) 関, 田中(和), 佐々木, 船石, 田中(信): 用水と廃水 40-6 pp.26-33(1998)

（9）吉田, 山崎, 岡村, 塩沢, 村林, 冨岡, 伊藤：水環境学会誌 21-10 pp.683689 (1998)

(10) 編集部, 取材協力, 今井敬義：ポリファイル 35-2 pp.17-19 (1998)

(11) ラドテック研究会年報 No.12 ラドテック研究会 (1999)

(12) ポリファイル 35-2 (1998)

(13) 編集部：ポリファイル $35-2$ pp.20-21 (1998)

(14) 旭電化工業：ポリファイル 35-2 pp.38-39 (1998)

(15) 東曲合成：ポリファイル $35-2$ pp.34-36 (1998)

(16) ローヌ・プーラン ジャパン：ポリファイル：ポリファイル 35-2 p. 42 (1998)

(17) 小林敬司：コンバーテック 26-8 pp.26-27（1998）

(18) 編集部：ポリファイル $35-2$ pp.25-27 (1998)

(19) 東芝ライテック：ポリファイル $35-2$ pp.28-30 (1998)

(20) フュージョン UV システム：ポリファイル $35-2$ pp.44-45 (1998)

(21) 圾下健司：月刊ディスブレイ 4-10 pp.37-40 (1998)

(22) 地江堅一：月刊ディスプレイ 4-10 pp.35-38（1998

(23) 小用, 菅原, 酒抹, 明不：照学全大 p.85 (1998)

(24) 広瀬, 阙本, 菅原, 松野：照学全大 p.86 (1998)

(25) 岡本, 朝比, 罍沼, 松野：照学全大 p.87 (1998)

(26) Daniel A Smith, etal: 電子材料 $37-3$ pp.78-83 (1998)

(27) 羽田英夫注か：電子材料 $37-3$ pp.84-88（1998）

(28) 馬立稔和ほか：電子材料 $37-3 \quad$ pp.89-94 (1998)

(29) 編集部：ポリファイル $35-11 \quad$ pp.45-49 (1998)

(30) 萩原茂：オプトロニクス 195 pp.157-161 (1998)

(31) 田上英二郎：ラドテック研究会年報No.12 ラドテック研究会 pp.219224 (1998)

(32) 第23回日本アイソトープ・放射線総合会議論文集 社団法人日本原子力産業会 議 (1998)

(33) 高山踩男：ラドテック研究会年報No.12 ラドテック研究会 pp.268 278 (1998)

(34) 松本真芳：放射線と産業 No.77 pp.15-18 (1998)

(35) 岩崎電気：ポリファイル $35-2$ pp.47-48 (1998)

(36) ウシオ電材：ポリファイル $35-2 \quad$ p.52 (1998)

（37）中村賢二ほか 医用衛生紫外線研究会誌 vol.17 pp.33-40 (1998)

（38）木下忍：包装技術 36-8 pp.14-21（1998）

(39) 木下忍：機能材料 $18-6$ pp.54-61 (1998)

(40) 田中丈之：マテリアルライフ学会 10-1 pp.25-29 (1998)

（41）浦辺修一，保士用善文：第9回マテリアル学会年次大会 pp.31-34（1998）

(42) テクニカルベーパー：自動車技術会 (1998)

(43) JASO 見格：白動車技術会 (1998)

\section{7 リモートセンシング}

まず地球観測衛星の動向について述べると，ランドサット5号 とスポット 2 号は1998年を通じて順調に動作している．3月には フランスの地球観測衛星シリーズであるポット 4 号が打ち上げら れた. スポット 4 号は HRVIR と Vegetation Instrumennt(VI) を搭載していて，HRVIRにはスポット 1 ～ 3 号にはなかった中 間赤外域のバンド $(1.58 \sim 1.75 \mu \mathrm{m})$ が付加されている。この波長 域は水分の吸収領域で，観測対象の水分含有量の情報を得ること が出来，このバンドは植生の分類に有効である.VIは地上分解能
$1 \mathrm{~km}$, 走查幅 $2250 \mathrm{~km}$ で観測し, 広域の植生分布情報を得ようとす るセンサーであるＨRVIR とほぼ同じ波長域で4つの観測バン ドが用意されているので，VIで広域を観测し，その一部を HRVIR で詳細に観測するというような利用方法が期待できる. スポット 4 号のデー夕は, 現在宇宙開発事業団の地球観測センター

(NASDA EOC) では受信していない.

日本の地球観測衛星 JERS- 1 が10月に運用を停止した. JERS 1 には合成開ロレーダー（SAR）と光学センサー（OPS）が搭載 
されていて，1992年の打ち上げ以来，予定のミッション期間の 2 年を大きく超えて運用され，これまでにトータル約 50 万の SAR データと約30万の OPS データが取得された. JESR-1 SARのデー 夕は陸域観測に適した L バンド（波長 $23 \mathrm{~cm}$ ) を使用しており, 現 在運用されているほかのレーダ搭載衛星（ERS- 2, RADAR-

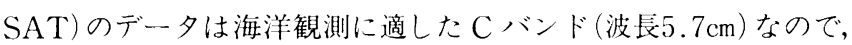
貴重であった. JESR-1 SARデー夕を使って，広大な熱帯雨林と 北半球の北方林のモザイク画像を作成するプロジェクトが, 宇宙 開発事業団の地球観測データ解析センター（NASDA EORC）が 主導して進められている。このプロジェクトの対象地域は地球最 大規模の森林带であり, 地球温暖化の大きな要因である炭酸がス の吸収帯であって, この森林带の監視は地球環境問題の重要なテ一 マである。これらの地域は降雨や降雪が多く, 光学センサーでは 観測困難であるが, 全天候で観測可能な SARによる監視が有効 である。このプロジェクトで作成された南米のアマゾン流域の熱 带雨林のモザイク画像が NASDA EORCから研究者に配布され ている.

1997年11月に打ち上げられた熱带地域の雲や降雨の観測を主目 的とする熱带降雨観測衛星（TRMM）は現在順調に動作してい る. 熱带地域の降雨は地球上の降雨の $2 / 3$ 以上を占め, 地球上 の水循環の重要な部分を占め, また大気循環の動力源であり,こ の観測は地球環境観测の重要なテ一マである。TRMMには降雨 量を観測する降雨レーダ(PR), 大気中の水蒸気観測に適したマイ ク口波放射計 (TMI)，可視から熱赤外域までの放射量を観測する 可視熱赤外観測装置（VIRS）などが搭載されている.PRのデー夕を使ってサイクロンや台風の降雨の 3 次元構造の解明, TMIの デー夕を使って海面温度分布情報による98年夏のエルニ一二ヨ現 象の観測, さらにVIRSのデー夕を使って水雲と積雲揖よび, 積 雲と巻雲の識別などがなされた。TRMMのデー夕は雨や雲が主 な観測対象なので，一般にはなじみがうすいかもしれないが，気 象関係の研究者には興味あるデー夕であり, PR, TMI, および VIRSのデータは 6 月から一般ユーザへの提供が(財リモート・セ ンシング技術センター（RESTEC）から開始された。

カナダの衛星 RADARSAT-1 およびインドの衛星 IRS-1Cと Dのデータは, NASDA が熊本の東海大学宇宙情報センタ一の場 所を借りて受信し, RESTECが処理を行う形で日本国内での受信 作業が進められ，IRS-1C とDのデー夕は11月から，RADASAT$1 の$ デー夕は99年 1 月から, RESTEC から一般ユ一ザへの提供が 開始された。これまでこれらの衛星による月本周辺の観測データ は, RADARSAT-1 はカナダのRSI 社, IRS-1CとDは米国の Space Imaging 社に依頼して取得してもらい, 送ってもらう必要 があった、日本での受信デー夕はRESTECのホームぺージ (http://www.restec.or.jp/) を通じてインターネットにより検索 可能でブラウズ画像も見ることができる. RADASAT-1 は, 全天 候観測可能な Cバンドのレーダーを搭載していて, ユーザの色々 な観測要求に忍えることができるように豊富な観測モードを持っ ていて, 入射角, 地上分解能, 観測幅を変之, しかも飛来時には 1 日に 2 回（夜明けと夕方）観測することができるので，災害地 点の高頻度観測には非常に有効である. IRS-1 C と D は, パンク ロバンドかつ高分解能 $(6 \mathrm{~m})$ で観測する Pan, 可視・近赤外・ 中間赤外域を 4 つのバンドかつ中分解能 $(23 \sim 70 \mathrm{~m})$ で観測する LISS- 3 および，広い範囲を（観測幅 $770 \mathrm{~km}$ ）を可視・赤外域 2 バ ンドかつ低分解能 $(190 \mathrm{~m})$ で観測する WiFSの 3 つのセンサーが 搭載されているが, Pan と LISS- 3 のみ日本で受信している.
高分解能 $(1 \mathrm{~m})$ デー夕が売り物の商業用リモートセンシング 衛星は, 1997年12月に EarthWatch 社の EarlyBirdが头敗した 後, Space Imaging 社の Ikonos-1 が, 当初1998年 5 月に打ち上 げられる予定であったが，結局1998年中には打ち上げられず，最 新の情報では1999年 4 月の打ち上げ予定となっている．ORBIMAGE 社が1997年 8 月に打ち上げた OrbView -2 は, 海洋の 海色やクロロフィルの分布の把握に適したセンサーSeaWiFを 搭載している. SeaWiF のデー夕は東海大学宇宙情報センターで 研究用に受信していて，NASDA は ADEOSが1997年 6 月に動作 停止したので，ADEOSに搭載されていた海色海温走查放射計 (OCTS)によるデー一タセッの代替として, 東海大学で受信した SeaWiFのデー夕を使ってクロロフィルや海面射出輝度などの データセットを作成し，研究者に配布することを1998年半ばころ から始めた。 ORBIMAGE 社は高分解能 $(1 \mathrm{~m})$ で陸域観測用の 衛星 OrbView-3 3 を1999年中に打ち上げる計画を持っている.

1998年 8 月，北朝鮮から発射されたミサイル，テポドンが日本 国土の上空を通過し，遥か東の太平洋に落下した事件をきっかけ に，日本国政府が情報収集衛星を2002年度中に保有する計画が急 遽決定した。この情報収集衛星は分解能 $1 \mathrm{~m}$ 以下の光学センサ一 㧍よび分解能 $3 \sim 5 \mathrm{~m}$ の SAR 在搭載した衛星各 2 機の合計 4 個 の衛星を打ち上げ，世界のどの地点の上空も少なくとも 1 月に 1 回は昼間の同時刻に通過し，観測しようとするものであり，シス テム設計が1999年年明けからスタートした。今のところデータの 利用は政府関係機関にしぼられ，一般には開放しない方針のよj であるが、これをきっかけに衛星りモ一トセンシングデー夕の利 用が推進されることは確かであろう。

1997年度の衛星デー夕の配布状況を述べておくと, ADEOS, IRSのデー夕配布が新しく始まったこと, 研究目的配布が非常に 増加したことにより，トータルの配布件数は1996年度に比べて約 30\%増加した．衛星別ではやはりランドサットが一番多く $43 \%$, 次に JERS-1，スポットと続き，以上の 3 つの衛星で77\%を占め ていて，1996年度ので91\%に比べて減少したが，これはトータル の配布件数が增加したことによる.利用機関別では学校など $28 \%$, 国立機関 $21 \%$ ，民間会社 $18 \%$ ，海外ユーザ14\%，公益法人 $11 \%$, 地方自体 $7 \%$ となっていて, 研究目的配布が増加したため学校な どが一番多くなっている.

リモートセンシング関係の国内の学会としては, 日本写真測量 学会と日本リモートセンシング学会の春と秋の学術講演会が例年 通り行われたが, 偶々再学会の開催場所が春は千葉, 秋は京都で 同じであった。これらの学会の対象分野は, 従来の土地, 地形の 観測・計測の分野から，画像処理やセンサ一技術などの飛躍的な 進歩を背景に，静止被与体だけでなく，移動被察体の位置や形状 を高精度にかつリアルタイムで観測・計測する分野にまで広がり つつある.地形の精密な面計測の最新技術として, SAR インタ一 フェロメトリーが注目されている。1998年にはリモートセンシン グ関係の国際学会が多く開かれたが，その最大のものはIEEEの GRSS（地球科学りモートセンシング部会）が主催するIGARSS '98であり，それが7月に米国のシアトルで開かれた。この学会で は, 米国の NASA やNOAA と並んでNASDA がスポンサーに なり，またADEOS, TRMMのセッションが設けられていたが, これは日本の地球観測活動が世界のなかでその役割を拡大しつつ あることの現れであろう。

（向井 幸男・財リモートセンシング技術センター） 


\section{8 電熱}

\section{8 .1 電熱の基礎}

放射（赤外放射，マイクロ波）による電気加熱技術の基礎的研 究開発の動向を述べる。

赤外放射加熱については，その特徵である“省エネルギ一性” をさらに向上させることをねらいとして，赤外加熱装置の工ネル ギーフローの検討結果が示され，このフローに基づいて省エネル ギーを推進するのための課題が提案された ${ }^{11}$.また，ボイケン・モ デルを拡張した模擬電気回路によるモデルによる，遠赤外放射加 熱を受ける含水物の加熱特性についての理論的考察がなされ，特 に定率乾燥初期までの期間における詳細な検討結果が示され $た^{223)}$.

マイクロ波加熱についての基礎的検討結果も多数発表され た ${ }^{4)-8)}$. 基本的特性と利点をまとめた内容の総説 ${ }^{4)}$ ，マイクロ波空 洞中の電場に扔ける数值的解析に関する研究 ${ }^{5)}$, 矩形導波管を用 いた多層物体加熱特性の研究6)は，マイクロ波加熱の忘用展開を 図るうえで有効と考えられる。

伝熱技術の基礎の関連では，山凸のある被加熱物体の加熱状況 の IR サーモグラフィーと画像処理技術による解析 ${ }^{9)}$, ソーラ屋根 の空気流と熱伝達に関导る研究 ${ }^{10)}$ ，有限要素法を用いた IH 炊飯 器の熱流体の解析 ${ }^{11)}$, 赤外イメ一泣炉による高温試験システムの 性能評価 ${ }^{22}$ ，などが進められた。

\section{8 .2 放射源}

放射電熱システム用の放射源については，オーブン制御水晶発 振器を利用した制御機構付きの赤外七一ターの開発 ${ }^{13)}$, 放射波長 域 $5 \sim 12 \mu \mathrm{m}$ の赤外自由電子レーザーの開発 ${ }^{14)}$, 放電ランプでポン ピングされた沃化酸素レーザーの効率に関する研究15)，大パワー の工業用マイクロ波加熱システム用に使用可能な大形のマグネト ロンの開発16)などの成果があった。

\subsection{3 電熱装置, 電熱システム}

放射電熱用の装置，電熱炉，電熱システムについては，赤外リ フロー炉のヒーターに関する放射・吸収特性についての熱解析の 結果と実際の炉の場合との対応の分析結果 ${ }^{17)}$, プラズマディスプ レイ装置の製造工程における, ペーストの乾燥, 感光剤の乾燥, シール材の乾燥・固化に使用される，熱風・赤外七ーター・ホッ ト・プレート併用形の乾燥装置の構造と特性 ${ }^{18)}$, 抵抗加熱式の小形 オーブンの製造の現状 ${ }^{19)}$ ，製品の生産状況に合わせて加熱スケジ ユールをプログラミング可能なマイクロ波・熱風併用形乾燥機の 特性20)などが発表された。

\section{8 .4 電熱の応用}

産業用加熱の分野を俯瞰守ると，赤外放射やマイクロ波，抵抗 加熱を中心とする電気エネルギーによる加熱は，製造者や処理者 が，生産性・品質の改善や工程のクリーンさを求めるに伴って, 応用分野がさらに広がってきている ${ }^{21}$. 個別技術としては, 新開発 の遠赤外アルミヒーターによる高速乾燥技術 ${ }^{22}$, 赤外放射・マイク 口波併用による水蒸気の移動と際分布を改良した食品加工装 置 ${ }^{23)}$, 熱放射検出形の鼓膜温体温計 ${ }^{24)}$, 熱有限要素法によるシミュ
レーションに基づく高性能 VLSI 加工炉 ${ }^{25)}$ ，新開発のセラミック マイクロヒーターによる精密な温度制御が可能な電熱七一ターカ

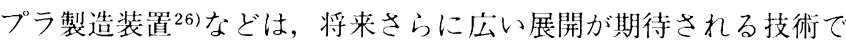
あると考えられる。

そのほか，半導体産業におけるリフロ一炉についても種々の新 技術が導入された27)-29).

マイクロ波加熱についても新開発の忘用技術がいろいろな方面 で導入された. 光学セラミックの接合装置 ${ }^{30)}$, 熱風併用の魚乾燥装 置 ${ }^{31}$ はそれらの代表例である。

\section{（水上 幸三・日本電熱協会）}

\section{考 文 献}

(1) 河本：電気学会光忍用・視覚研究会資料 LAV-97 No.7 pp.19-23 1997

(2) 中尾：エレクトロヒート No.100 pp.48-54 (1998

（3）中尾，市川：照学誌 $82-5$ pp.327-335 (1998)

(4) Snow, E.F., Fox, J. : Reg. Tech. Conf. Broader Mean Thermosets 1998 pp.79-88 (1998

(5) Cho, S.H., Kang, H.J. : Proc. 33rd Microwave Power Symposium 1998 pp.13-16 (1998)

（6）青木，赤堀，横山，山野：日本機械学会熱工学部門講演会講演論文集 Vol.1998 pp.235-236 (1998)

(7) Kasevich, R.S. : Proc. 33rd Microwave Power Symposium 1998 pp.103106 (1998)

(8) Lee, N.C. : Proc. Tech. Program Surf. Mt. International Conference Exposition 1998 pp.4-35 (1998)

(9) Pelletier, J.F., Maldague, X. : Opt. Eng. 36-2 pp.370-375 (1998)

(10) Sandberg, M., Moshfegh, B. : Renew Energy 15-1/4 pp.287-292 (1998

(11) 位々木, 崎山, 弘田, 藤田, 川下, 大森：パワーエレクトロニクス研究会論文 誌 24-1 pp.27-34 (1998)

(12) Taya, M., Kobayashi, A., Jenkins, M. : AD Report AD-A-331183 p.11 (1998)

(13) Balaz, I., Minarik, M. : Proc. IEEE Int. Freq. Control Symposium Vol 50th pp.674-680 (1996

（14）富增：光学 $27-8$ pp.432-433 1998

(15) Akatsuka, H., Ezoubtchenko, A.N., Suzuki, M. : Bull. Research Laboratory NuclearReaction Vol 22 p.34 1998

(16) Rutherford, R.J., Zhu, J. : Proc. 33rd Microwave Power Symposium 1998 pp.25-28 (1998)

(17) 内田，作山，名取，河原出，赤井：Symposium Microjoining Assem. Tech nologyElectron Vol 4th pp.193-198 (1998)

(18) 下瀬：電子材料 37-12 pp.80-81 (1998)

(19) Appliance 55-10 pp.44-46 (1998

(20) Tran, N. : Proc. 33rd Microwave Power Symposium 1998 pp.33-34 (1998

(21) Bateman, J. : Electrotechnology 9-1 pp.6-9 (1998)

(22) 木下：エレクトロニクス尖相技術 $14-5$ pp.36-40 (1998)

(23) Ni, H., Datta, A.K. : Proc. 32nd Microwave Power Symposium 1997 pp.1315 (1997)

(24) 藤原：電気学会光匛用・視敩研究会資料 LAV-97 No.7 $\quad$ pp.13-17 (1997)

(25) Rzepka, S., Meusel, E. : IEEE Trans. Component Package Manufacturing Tech. Part A 21-3 pp.406-411 (1998)

(26) 植竹，飛田，小林：電子材料 38-1 pp.54-57 1999)

(27) Thor, V., Appel, K., Nover, M., Sommerfeld, P. : Proc. IEEE/CPMT Int ElectronicManufacturing Technology Symposium Vol. 22nd pp.27-30 1998

(28) Burress, R.V. : Proc. Tech. Program Surf. Mt. International Conference Exposition 1998 pp.693-698 (1998)

(29) 川崎, 谷上: Omron Technology 38-3 pp.259-262 (1998)

(30) Case, E.D., Lee, K.Y., Lee, J.G. : Proc. 33rd Microwave Power Symposium 1998 pp.33-34 (1998)

(31) Tran, N., Piotrowski, A. : Proc. 33rd Microwave Power Symposium 1998 pp.59-62 (1998) 